\title{
Rypsin fenoleiden eristäminen ja bioaktiivisuus
}

\author{
Vuorela, S. \& Heinonen, M. \\ Helsingin yliopisto, Soveltavan kemian ja mikrobiologian laitos, PL 27 Elintarvikekemia, 00014 \\ Helsingin yliopisto
}

Rypsiöljyn (Brassica rapa) ja rypsirouheen fenolisia yhdisteitä ja niiden erilaisia bioaktiivisuuksia tutkittiin Tekes-rahoitteisessa "Elintarvikkeet ja terveys" -teknologiaohjelman hankkeessa. Rypsi, eräät marjat sekä männynkuori valikoituivat n. 100 tutkitun kasvimateriaalin joukosta jatkotutkimuksiin. Rypsin fenolisten yhdisteiden osalta bioaktiivisten ominaisuuksien tutkiminen keskittyi vaikutuksiin antioksidanttina, mutta myös antimikrobisia vaikutuksia, tulehduksen estovaikutuksia sekä antimutageenisia vaikutuksia tutkittiin yhteistyössä muiden tutkimusryhmien kanssa. Tutkimuksessa selvitettiin erilaisten eristystekniikoiden vaikututusta rypsin fenolisten yhdisteiden talteenottoon sekä rypsirouheen ja erilaisten rypsistä eristettyjen uutteiden soveltuvuutta elintarvikkeiden, kuten lihatuotteiden, raaka-aineeksi.

Rypsin fenolisten yhdisteiden pitoisuudet määritettiin HPLC-menetelmällä rypsirouheesta ja erilaisista rypsiöljyistä, joista osa oli kaupallisia öljyjä ja osa raakaöljyjä rypsiöljyn valmistuksen eri vaiheista. Rypsirouhe eli rypsiöljyn puristuksen sivutuote, sisälsi runsaasti fenolisia yhdisteitä. Öljyssä näitä yhdisteitä oli huomattavasti vähemmän eli pääosa fenolisista yhdisteistä jää rouheeseen öljynpuristuksen yhteydessä. Rypsirouheen ja raakaöljyn fenoliset yhdisteet ovat osittain erilaisia, mikä johtuu siitä, että puristettaessa rypsinsiemenistä öljyä korkeassa lämpötilassa ja paineessa tapahtuu yhdisteissä rakenteellisia muutoksia. Eräs tällä tavoin muuntuneista yhdisteistä on vinyylisyringoli, joka syntyy sinappihaposta. Vinyylisyringoli on raakaöljyn yleisin fenolinen yhdiste, jota ei enää ole kaupallisessa puhdistetussa rypsiöljyssä. Rypsirouheessa on eniten sinapiinia, joka on sinappihapon koliiniesteri ja sinappihappoa. Tutkimuksen eräs tavoite oli kehittää sellainen tekniikka, jonka avulla rypsin fenoliset yhdisteet voidaan eristää rypsirouheesta ilman haitallisia liuottimia. Fenoliset yhdisteet eristettiin mm. käyttämällä kuumaa vettä tai entsyymejä, kuten ferulahappoesteraasia. Nämä menetelmät osoittautuivat lähes yhtä tehokkaiksi kuin rypsin fenolisten yhdisteiden eristämisessä perinteisesti käytetty veden ja metanolin seos.

Eri tavoilla eristettyjen rypsin fenolisten uutteiden bioaktiivisia vaikutuksia tutkittiin erilaisissa olosuhteissa, jotka mallinsivat elintarvikkeita tai ihmisen soluja. Kaikki tutkitut rypsin uutteet estivät tehokkaasti ihmisen verestä eristetyn lipoproteiinin (LDL) sekä myös fosfatidyylikoliinista rakentuneen liposomi-membraanin hapettumista eli ne toimivat tehokkaina antioksidantteina. Rypsinsiemenistä jälkipuristustekniikalla saadusta raakaöljystä eristetty fenolisia yhdisteitä sisältävä uute toimi myös tehokkaana radikaalinsieppaajana (DPPH-testi). Rypsin fenoliset yhdisteet paransivat myös kypsennetyn jauhelihan säilymistä estämällä lihan härskiintymistä. Rypsirouhe oli myös sellaisenaan tehokas lihatuotteen antioksidantti, joskin rouhe sisältää fenolisten yhdisteiden lisäksi myös monia muita ainesosia, kuten valkuaisaineita, joilla saattoi myös olla edullinen vaikutus lihan säilyvyyteen. Rypsin raakaöljystä eristetty uute vaikutti myös eräiden elimistössä tulehduksien yhteydessä muodostuvien tulehdusvälittäjäaineiden, prostaglandiinin ja typpioksidin syntymiseen eli sillä todettiin olevan tulehduksia estäviä vaikutuksia. Rypsistä eristetyt fenoliset aineet eivät osoittautuneet myrkyllisiksi eikä niiden myöskään todettu lisäävän kasvaimien muodostumista, päinvastoin, esim. vinyylisyringolilla saattaa olla kasvainten muodostumista ehkäisevää vaikutusta. Tutkimuksessa saadut tulokset ovat siten lupaavia ajatellen mahdollisia hyötyjä terveysvaikutteisten elintarvikkeiden tai lääkkeiden ja kosmetiikkatuotteiden kehitystyössä.

Vuorela, S. 2005. Analysis, isolation, and bioactivities of rapeseed phenolics. Väitöskirja. EKT-sarja 1343. Helsingin yliopisto, Soveltavan kemian ja mikrobiologian laitos.

Asiasanat: Rypsi, rypsiöljy, rypsirouhe, fenoliset yhdisteet, sinappihappo, vinyylisyringoli, antioksidanttivaikutus, bioaktiivisuus 


\section{Johdanto}

Rypsiöljyn (Brassica rapa) ja rypsirouheen fenolisia yhdisteitä ja niiden erilaisia bioaktiivisuuksia tutkittiin Tekes-rahoitteisessa "Elintarvikkeet ja terveys" -teknologiaohjelman hankkeessa. Rypsi, eräät marjat sekä männynkuori valikoituivat n. 100 tutkitun kasvimateriaalin joukosta jatkotutkimuksiin. Rypsin fenolisten yhdisteiden osalta bioaktiivisten ominaisuuksien tutkiminen keskittyi vaikutuksiin antioksidanttina, mutta myös antimikrobisia vaikutuksia, tulehduksen estovaikutuksia sekä antimutageenisia vaikutuksia tutkittiin yhteistyössä muiden tutkimusryhmien kanssa. Tutkimuksessa selvitettiin erilaisten eristystekniikoiden vaikututusta rypsin fenolisten yhdisteiden talteenottoon sekä rypsirouheen ja erilaisten rypsistä eristettyjen uutteiden soveltuvuutta elintarvikkeiden, kuten lihatuotteiden, raaka-aineeksi.

\section{Aineisto ja menetelmät}

Rypsin fenolisten yhdisteiden pitoisuudet määritettiin HPLC-menetelmällä (Koski ym. 2003) rypsirouheesta ja erilaisista rypsiöljyistä, joista osa oli kaupallisia öljyjä ja osa raakaöljyjä rypsiöljyn valmistuksen eri vaiheista. Kokonaisfenolipitoisuus määritettiin spektrofotometrisesti FolinCiocalteau -menetelmällä. Fenoliset yhdisteet eristettiin mm. käyttämällä kuumaa vettä tai erilaisia entsyymejä (ferulahappoesteraasi, esteraasi, Viscozyme, Ultraflo, Celluclast). Eri tavoilla eristettyjen rypsin fenolisten uutteiden bioaktiivisia vaikutuksia tutkittiin olosuhteissa, jotka mallinsivat joko elintarvikkeita tai ihmisen soluja. Antioksidanttivaikutusta tutkittin sekä ihmisen verestä eristetyn lipoproteiinin (LDL) että fosfatidyylikoliinista rakentuneen liposomi-membraanin hapettumisen estäjänä. Teoreettista kykyä toimia vapaiden radikaalien sieppaajana tutkittiin DPPH-testillä. Elintarvikesovelluksena tutkittiin rypsin fenolisten yhdisteiden kykyä parantaa kypsennetyn jauhelihan säilymistä estämällä lihan härskiintymistä. Antimikrobisia vaikutuksia erilaisten ihmisen suolistobakteerien (K.oxytoca, S. typhimurium, L. Acidophilus, L. crispatus, E.coli ja P. mirabilis) ) kasvunestäjinä, tulehduksen estovaikutuksia $\mathrm{COX}_{2}$-välitteisissä reaktioissa sekä antimutageenisia vaikutuksia tutkittiin yhteistyössä muiden tutkimusryhmien kanssa. Tutkimusmenetelmät on tarkemmin kuvattu väitöskirjatyössä (Vuorela 2005) sekä julkaisuissa (Vuorela ym. 2003, Vuorela ym. 2004, Vuorela ym. 2005a ja Vuorela ym. 2005b)

\section{Tulokset ja tulosten tarkastelu}

Rypsin fenolisten yhdisteiden pitoisuudet määritettiin rypsirouheesta ja erilaisista rypsiöljyistä, joista osa oli kaupallisia öljyjä ja osa raakaöljyjä rypsiöljyn valmistuksen eri vaiheista (Kuva 1 ja Taulukko 1). Rypsirouhe eli rypsiöljyn puristuksen sivutuote, sisälsi runsaasti fenolisia yhdisteitä. Öljyssä näitä yhdisteitä oli huomattavasti vähemmän eli pääosa fenolisista yhdisteistä jää rouheeseen öljynpuristuksen yhteydessä. Rypsirouheen ja raakaöljyn fenoliset yhdisteet ovat osittain erilaisia, mikä johtuu siitä, että puristettaessa rypsinsiemenistä öljyä korkeassa lämpötilassa ja paineessa tapahtuu yhdisteissä rakenteellisia muutoksia. Eräs tällä tavoin muuntuneista yhdisteistä on vinyylisyringoli, joka syntyy sinappihaposta. Vinyylisyringoli on raakaöljyn yleisin fenolinen yhdiste, jota ei enää ole kaupallisessa puhdistetussa rypsiöljyssä. Rypsirouheessa on eniten sinapiinia, joka on sinappihapon koliiniesteri ja sinappihappoa. Tutkimuksen eräs tavoite oli kehittää sellainen tekniikka, jonka avulla rypsin fenoliset yhdisteet voidaan eristää rypsirouheesta ilman haitallisia liuottimia. Fenoliset yhdisteet eristettiin mm. käyttämällä kuumaa vettä tai entsyymejä, kuten ferulahappoesteraasia. Nämä menetelmät osoittautuivat lähes yhtä tehokkaiksi kuin rypsin fenolisten yhdisteiden eristämisessä perinteisesti käytetty veden ja metanolin seos (Kuva 2) . 


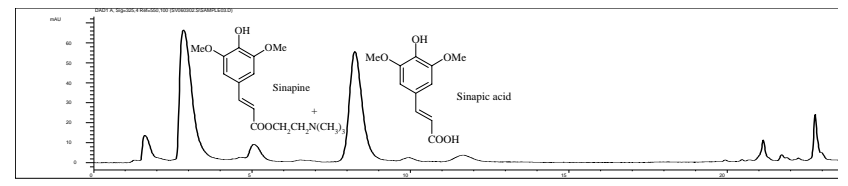

a) $325,4 \mathrm{~nm}$

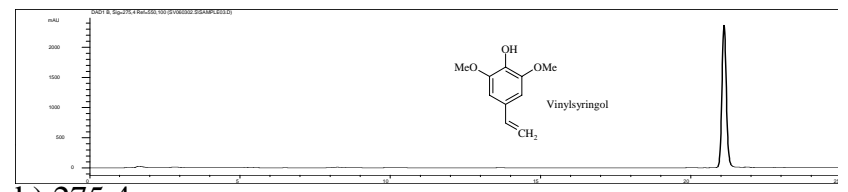

b) $275,4 \mathrm{~nm}$

Kuva 1. Jälkipuristetun käsittelemättömän rypsiöljyn fenolisten yhdisteiden HPLC-analyysi: a) sinapiini ja sinappihappo, b) vinyylisyringoli (Vuorela ym. 2003).

Taulukko 1. Sinapiinin, sinappihapon, vinyylisyringolin ja kokonaisfenolien määrä ( $\mu \mathrm{g} / \mathrm{g} \mathrm{SAE}$ ) rypsirouheessa sekä eri tavoin prosessoiduissa rypsiöljyissä (Vuorela ym. 2003).

\begin{tabular}{lccccc}
\hline & Sinapiini & $\begin{array}{c}\text { Sinappi- } \\
\text { happo }\end{array}$ & $\begin{array}{c}\text { Vinyyli- } \\
\text { syringoli }\end{array}$ & Yhteensä & $\begin{array}{c}\text { Kokonais- } \\
\text { fenolit }\end{array}$ \\
\hline Rouhe & 5048 & 454 & - & 5502 & 11183 \\
Öljy 1 & 0 & 0 & 0 & 0 & 0 \\
Öljy 2 $^{2}$ & 0 & 0 & 0 & 0 & 25 \\
Post $^{3}$ & 19 & 16 & 244 & 279 & 439 \\
Pre $^{4}$ & 4 & 4 & 4 & 12 & 25 \\
Sdg $^{5}$ & 0 & 7 & 47 & 54 & 82 \\
\hline
\end{tabular}

1), 2) kaupallinen rypsiöljy 3), jälkipuristettu käsittelemätön rypsiöljy, 4) käsittelemätön rypsiöljy ja 5) ”superdegummed” rypsiöljy

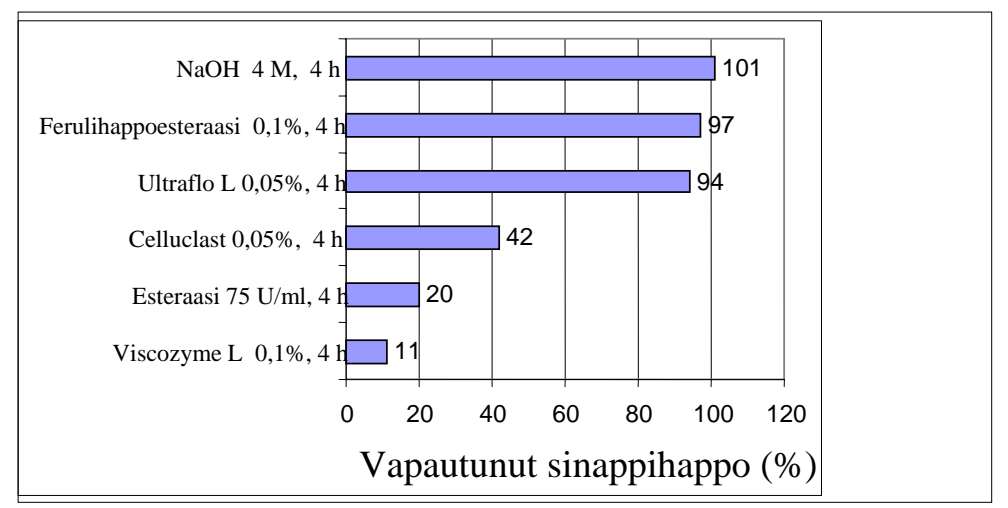

Kuva 2. Vapautuneen sinappihapon määrä (\%) eristettäessä rypsirouheen fenolisia yhdisteitä eri tekniikoin: emäshydrolyysi (NaOH) ja entsymaattiset käsittelyt (Vuorela ym. 2004).

Eri tavoilla eristettyjen rypsin fenolisten uutteiden bioaktiivisia vaikutuksia tutkittiin erilaisissa olosuhteissa, jotka mallinsivat elintarvikkeita tai ihmisen soluja. Kaikki tutkitut rypsin uutteet estivät tehokkaasti ihmisen verestä eristetyn lipoproteiinin (LDL) sekä myös fosfatidyylikoliinista rakentuneen liposomi-membraanin hapettumista eli ne toimivat tehokkaina antioksidantteina (taulukko 2). Rypsinsiemenistä jälkipuristustekniikalla saadusta raakaöljystä eristetty fenolisia yhdisteitä sisältävä uute toimi myös tehokkaana radikaalinsieppaajana (DPPH-testi). Rypsin fenoliset 
Taulukko 2. Eri tekniikoin eristettyjen rypsirouheen fenolisten yhdisteiden antioksidanttivaikutus (\%, heksanaalin muodostumisen inhibitio) liposomi-membraanin ja LDL-partikkelin hapettumisen estäjinä (Vuorela ym. 2004).

\begin{tabular}{|lll|}
\hline Eristysmenetelmä & Liposomi $(8,4 \mu \mathrm{g} / \mathrm{ml})$ & LDL $(4,2 \mu \mathrm{g} / \mathrm{ml})$ \\
\hline $70 \%$ metanoli vedessä & $99,3 \pm 0,07$ & $94,8 \pm 2,48$ \\
70 \% etanoli vedessä & $99,4 \pm 0,05$ & $96,3 \pm 0,33$ \\
Kuuma vesi & $98,4 \pm 0,26$ & $93,0 \pm 3,24$ \\
Ferulahappoesteraasi & $97,6 \pm 0,16$ & $97,8 \pm 0,45$ \\
\hline
\end{tabular}

yhdisteet paransivat myös kypsennetyn jauhelihan säilymistä estämällä lihan härskiintymistä (Vuorela ym. 2005b). Rypsirouhe oli myös sellaisenaan tehokas lihatuotteen antioksidantti, joskin rouhe sisältää fenolisten yhdisteiden lisäksi myös monia muita ainesosia, kuten valkuaisaineita, joilla saattoi myös olla edullinen vaikutus lihan säilyvyyteen. Rypsin raakaöljystä eristetty uute vaikutti myös eräiden elimistössä tulehduksien yhteydessä muodostuvien tulehdusvälittäjäaineiden, prostaglandiinin ja typpioksidin syntymiseen eli sillä todettiin olevan tulehduksia estäviä vaikutuksia (Vuorela ym. 2005a). Rypsistä eristetyt fenoliset aineet eivät osoittautuneet myrkyllisiksi eikä niiden myöskään todettu lisäävän kasvaimien muodostumista, päinvastoin, esim. vinyylisyrigolilla saattaa olla kasvainten muodostumista ehkäisevää vaikutusta (Vuorela ym. 2005a). Tutkimuksessa saadut tulokset ovat siten lupaavia ajatellen mahdollisia hyötyjä terveysvaikutteisten elintarvikkeiden tai lääkkeiden ja kosmetiikkatuotteiden kehitystyössä.

\section{Kirjallisuus}

Koski, A., Pekkarinen, S., Hopia, A., Wähälä, K. \& Heinonen, M. 2003. Processing of rapeseed oil: effect on sinapic acid derivative content and oxidative stability. Eur. Food Res. Technol. 217: 110-114.

Vuorela, S. 2005. Analysis, isolation, and bioactivities of rapeseed phenolics. Väitöskirja. EKT-sarja 1343. Helsingin yliopisto, Soveltavan kemian ja mikrobiologian laitos.

Vuorela, S., Meyer, A.S. \& Heinonen, M. 2003. Quantitative analysis of the main phenolics in rapeseed meal and oils processed differently using enzymatic hydrolysis and HPLC. Eur. Food Res. Technol. 217: 517-523.

Vuorela, S., Meyer, A.S. \& Heinonen, M. 2004. Impact of isolation method on the antioxidant activity of rapeseed meal phenolics. J. Agric. Food Chem., 54:8202-8207.

Vuorela, S., Kreander, K., Karonen, M., Nieminen, R., Hämäläinen, M., Galkin, A., Laitinen, L., Salminen, J-P., Moilanen, E., Pihlaja, K., Vuorela, P., Vuorela, H. \& Heinonen, M. 2005a. Preclinic evaluation of rapeseed, raspberry and pine bark phenolics for health related effects. J. Agric. Food Chem., 53: 5922-5931.

Vuorela, S., Salminen, H., Mäkelä, M., Karonen, M., Kivikari, R. \& Heinonen, M. 2005b. Effect of plant phenolics on protein and lipid oxidation in cooked meat patties. J. Agric. Food Chem., 53: 8492-8497. 